The University of Maine

DigitalCommons@UMaine

10-1984

\title{
Gay Movements and Legal Change: Some Aspects of the Dynamics of a Social Problem
}

Steven F. Cohn

James E. Gallagher

Follow this and additional works at: https://digitalcommons.library.umaine.edu/soc_facpub

Part of the Gender and Sexuality Commons, and the Sexuality and the Law Commons

This Article is brought to you for free and open access by DigitalCommons@UMaine. It has been accepted for inclusion in Sociology School Faculty Scholarship by an authorized administrator of DigitalCommons@UMaine. For more information, please contact um.library.technical.services@maine.edu. 


\title{
GAY MOVEMENTS AND LEGAL CHANGE: SOME ASPECTS OF THE DYNAMICS OF A SOCIAL PROBLEM*
}

\author{
STEVEN F. COHN \\ JAMES E. GALLAGHER \\ University of Maine at Orono
}

\begin{abstract}
This paper examines public opinion and media coverage surrounding four important events which affected the development of homosexual rights in Maine in the 1970s: the birth of a homosexual student group on a University of Maine campus and the conference it organized; the adoption of a gay rights plank in the election platform of the state's Democratic Party; revisions to the state's criminal code which decriminalized homosexual activities; and a second conference organized by the student group. Only the first event aroused major public outcry. We describe these events in detail, examine how the media covered them, and analyze why some were more controversial than others. Our analysis shows how differing levels of control over the media affect the rise and resolution of public issues.
\end{abstract}

Between September 1973 and June 1975 the state of Maine was the site of four important developments concerning the rights of homosexuals: (1) In September 1973 a homosexual student group, containing both males and females, formed on the campus of the University of Maine at Orono. It planned a conference on gay rights to be held the following April. The announcement of the conference in January 1974 sparked a controversy which continued until the conference was held. (2) In May 1974 the Maine Democratic Party adopted a gay rights plank in its platform, reigniting the controversy aroused by the gay conference. (3) In June 1975 the state legislature decriminalized homosexual intercourse, among both female and males, as part of a major revision of the state criminal code. The decriminalization aroused virtually no public controversy. (4) In the Spring of 1975 the University of Maine group held a second conference on gay rights. Virtually no controversy accompanied this conference.

This paper describes these events and the controversy surrounding some of them in an attempt to explain why some, but not all, of the events became controversial. In so doing, we hope to contribute to the understanding of how the process of definition of public issues takes place. We describe first our method, second the events and controversies, and third, the media coverage. Finally, we interpret the data. In the conclusion we relate this case study to literature on the "claimsmaking process" in the definition of social problems as described in the "subjectivist" school of social problems.

\section{METHOD}

In 1976-1977, almost two years after the second conference on gay rights, we conducted a series of interviews about these events. We interviewed state legislators from the Democratic and Republican parties. We selected party leaders because we believed they were well placed to provide information on how relevant legislative decisions were made. We checked this information with one of the principal journalists covering the state legislature. We interviewed one of the senior editors of the Bangor Daily News to determine the policies affecting the paper's coverage of these events, and we interviewed one of the principal political reporters on this paper to determine reporters' definitions of a "good story." We also interviewed three senior members of the University of Maine administration, two of whom had extensive contact with the university's board of trustees. We

\footnotetext{
* The authors thank Steven Barkan, Patricia LeBlanc, and the editors and reviewers of Social Problems for their help. Correspondence to: James E. Gallagher, Department of Sociology and Social Work, University of Maine at Orono, Orono, ME 04469.
} 
interviewed one member of the legal commission which proposed the decriminalization of homosexual intercourse and checked his information in interviews with two people occupying prestigious positions in the Maine legal community. We also interviewed one of the three fundamentalist ministers who led the protest against the first gay conference. Finally, we interviewed the local prosecuting attorney and police chief and the president of the University of Maine at Orono's gay organization.

We promised anonymity to each of the persons interviewed. Quotations in this paper which are not otherwise attributed are taken from these interviews. Each interview was tape recorded and transcribed. If the first transcription revealed incomplete or potentially biased information, we conducted a second interview. The principal weakness in our research is that we interviewed only one of the fundamentalist ministers who led the protest against the first gay conference. Our picture of the ministers' roles in these events may, therefore, not be complete.

We also studied the contents of major state newspapers during each of the events. Most of our analysis is based upon readings of the Bangor Daily News from April 1 to May 31, 1973; January 2 to July 31, 1974; and March 10 to June 20, 1975. The News devoted more space to state political and economic news than any other daily and was the dominant source of state news for northern and central Maine, where both the state capital and the University of Maine at Orono are located. We recorded the number of relevant articles, editorials, guest editorials, and letters to the editor in the News, their length (number of lines) and their locations in the paper. We measured the extent to which stories reported the opinions of spokespersons by counting the number of lines in each story reporting their statements.

We also read one issue in three of the Portland Press Herald and its associated paper, the Maine Sunday Telegram, and a one-in-six sample of issues of the other major state papers: the Sun-Journal, Morning Sentinel, Kennebec Journal, and Star-Herald. We did not conduct a systematic analysis of the radio and television news and comment programs as, in Maine, these played a secondary role in providing state and local news. We did, however, listen to a wide range of programs and summarized their contents.

\section{THE WILDE-STEIN CLUB AND THE APRIL 1974 GAY CONFERENCE}

In April 1973 a homosexual group called Gay Support and Action was organized in Bangor, Maine, a city of 38,000 people located 10 miles from the campus of the University of Maine at Orono (UMO). The group was an outgrowth of a non-credit course on homosexuality taught at the university. The course was taught at a time when gays were already mobilizing in urban areas. One goal of the person teaching the course was to stimulate mobilization in the Bangor area.

The club, which contained both men and women, initially had about 30 members, most of whom were students. It was formed in Bangor rather than at the university because many of the student members wanted the greater anonymity that meeting in Bangor could afford. By the summer the students' fears of being recognized on campus as gay had declined and they decided to form a separate gay club on campus. In September 1973 the Wilde-Stein Club held its first meeting, which was announced in the Maine Campus (hereafter, Campus), the UMO student newspaper.

The student senate granted probationary recognition to the club in October 1973, and final recognition came in October 1974. Student organizations are customarily given a one-year, probationary recognition. During that year they are accorded all rights and privileges, except funding. If the probationary year is completed without violating university rules, clubs are given full recognition and may request funding from the student senate.

The club's founders intended it as a means for advocating the rights of homosexuals, promoting the recognition of homosexuality as a normal expression of sexuality, and eliminating homosexual stereotypes. Initially, however, the activities of the club were limited to meetings and activities such as informal get-togethers intended to develop a "sense of community" among homosexual students 
(Maine Campus, 1973b).

The first major step in advocacy was taken by the members of the club in November 1973, when members planned a state-wide gay conference to bring together a number of gay support groups. The club planned to hold the conference on university grounds. The right to use university facilities for conferences was normally granted to clubs recognized by the student senate.

The original date for the conference was to be February 1974. However, the conference was twice postponed because of conflict on the UMO campus. The conflict began in November 1973 when a club member gave notice of a forthcoming gay dance to The Associated Press news agency. This AP notice was read by the head of the Christian Civic League of Maine, Reverend Benjamin Bubar. He issued a strong statement attacking the Wilde-Stein Club and its recognition by the university and condemning Bangor as a hot-bed of homosexual activity (Bangor Daily News, 1974a).

The story of Reverend Bubar's statement was the first report on the existence of the club that we found in the mass media, though the club was the topic of several stories in the student newspaper. University administrators told us that this statement was the first instance of public protest and that, after this statement but before the announcement of the conference, the university received only a few phone calls protesting the club's existence. Similarly, there was little controversy among the student body. For example, only three letters to the editor about the club appeared in the Campus prior to the public announcement of the conference. Only one letter criticized the club, and this criticism was limited to a discussion of whether adverse publicity might harm the university.

Following Bubar's statement, however, the Wilde-Stein Club encountered increasing difficulties in planning the conference. The club was twice forced to postpone the conference when the university refused to allow use of campus conference facilities. In both cases, the university justified the cancellations because of fuel shortages. The decisions to cancel the conference were made by President Howard Neville who took direct responsibility for dealing with the club. In a January 25, 1974 editorial the Campus (1974a), accused President Neville of a month-long effort to minimize the role of the club at the university because of Reverend Bubar's attacks.

When the university cancelled the conference for the third time, the Wilde-Stein Club threatened legal action and retained a Bangor attorney. A confrontation was averted when President Neville referred the matter to the university's board of trustees, the governing body for the seven campuses making up the University of Maine system. On January 23, 1974 the board of trustees approved the use of university facilities for the conference (Bangor Daily News, 1974b; hereafter the News).

After the trustees' decision was announced, a group of fundamentalist ministers tried to stop the conference, disband the club, and punish the university. In addition to Reverend Bubar, this group consisted of the head of a fairly large and rapidly expanding Baptist Church in Bangor and two Pentecostal ministers, one from Bangor and one from a town outside Bangor. The ministers urged their congregations to write and call the university and public officials demanding that the conference be cancelled. As a result, the News started to receive and publish a large number of letters. These in turn elicited letters in defense of the club and the university's decision.

The letter writers fell into three groups:

(1) a group supporting the club and sympathetic to the particular deprivations experienced by homosexuals;

(2) a group supporting the decision of the trustees on civil libertarian grounds; and

(3) a group hostile both to homosexuals and to the decision of the trustees.

Support for the club came from people who identified themselves either as homosexuals or as deeply sympathetic to homosexuals. This group emphasized the belief that people have a right to personal self-fulfillment. Support for the university was based upon a civil libertarian ideology, and demanded that the rights of homosexuals be recognized not as a particular group but as one of many groups whose civil rights were abridged. In contrast, the hostile group justified their position on the basis of sexual injunctions in the Bible and traditional family and social structures. 
The debate among these groups was intense. By the last week in February 1974, the News was printing an average of three letters a day on this issue. On March 22 the News announced that it would not publish any letters received after that date concerning the homosexual issue but that it would publish letters previously received. The paper received so many letters before March 22 that it continued publishing letters until April 18. Further, the News did not print all the letters it received, but excluded scurrilous, unintelligible, and unsigned letters. The number of letters (85) printed is even more impressive when one realizes that Maine's population at the time was only 987,722 . During this period, the university received a large number of phone calls and deputations from citizens protesting the trustees' decision. The extent of public protest was so great that a large proportion of the daily activities of the office of the Vice-President for Student Affairs was devoted to responding to these concerns.

The ministers were able to reach a large number of people not only through appeals to their own congregations, but through their use of the broadcast media. Several fundamentalist ministers had regularly-scheduled television or radio programs. Some of these programs used the air time to state the fundamentalist position on the issue. The ministers' ability to use the airwaves, however, was soon curtailed when the radio program of one minister was cancelled as was a talk show. Both these programs had devoted considerable air time to discussing the fundamentalist position. An article in the News alleged that "several other fundamentalist ministers with TV and radio programs have been bluntly warned to lay off the homosexual issue or have their programs cancelled" (Bangor Daily News, 1974f).

We do not have consistent evidence as to why the station manager decided to cancel the two programs. The manager stated that "the decision to remove both shows was made on 'programming' factors before the gay convention issue ever arose" (Bangor Daily News, 1974f). However, the reporter who covered the story wrote that he had evidence indicating that the decisions were made in response to pressures brought by prominent legislative supporters of the university (Bangor Daily News, 1974f).

In spite of the controversy, the university's board of trustees did not change its decision; it reaffirmed its position that the university should be open to a variety of ideas and stances. In addition to its commitment to intellectual freedom, the university knew it had no legal basis for dissolving the club and that it would be on shaky legal grounds if it denied the club the use of university conference facilities. Shortly before the trustees' decision, a Federal District Court ruled that the University of New Hampshire had to grant its student gay organization the rights of other student clubs (Gay Students Organization of the University of New Hampshire v. Bonner, 1974). A legal precedent for the Maine organization was thus established.

On February 27 the university's chancellor, Donald McNeil, attacked the News for its handling of the controversy. He stated that through its extensive coverage the News "was blowing the issue out of proportion" (Bangor Daily News, 1974e). The university had good reason to fear the controversy and negative reactions from the more religiously and socially conservative public. The university was in a vulnerable fiscal position for two reasons. First, the state budget, including the university's portion, was being considered during March of 1974. Second, the Orono campus was vulnerable because it was engaged in an extensive fund-raising drive.

The university was, therefore, vulnerable in two arenas: the legislature and public opinion. The ministers instigated a letter-writing campaign toward the state legislature; individual ministers and members of their congregations personally contacted legislators; and one minister addressed the appropriations committee of the state's Senate. The ministers demanded that (1) the university be forced to cancel the conference; and (2) its budget be cut as punishment.

The ministers received support from a relatively small group of conservative legislators who were adamantly opposed to the conference and the existence of the gay club. One reporter estimated them to comprise no more than one-quarter of the legislators (Bangor Daily News, 1974i). 
The state budget had two parts. Part 1 , totalling $\$ 173.7$ million, included $\$ 35$ million for the university's regular appropriation. Part 2 included $\$ 1$ million for capital improvement projects at the university. On March 7 the legislature approved Part 1 in a "wild session" after an "emotional two hour debate" in which members of the club were called, among other things, "a pack of queers." The debate was launched by one legislator who argued "They're a group of unbridled, ultra-liberal individuals. . . Nothing is more dangerous for society. . . . Professors as well as gay libbers fit into this category" (Bangor Daily News, 1974g).

Although the entire budget was passed, the legislative uproar continued. In Maine, legislators have the option of making changes in appropriations bills until the final day of the legislative session. On March 20 the Bangor Daily News (1974h) reported that several conservative members of the Appropriations Committee intended to use the university appropriation to force the university "to shut the door on the gay convention." They hoped to recommend that the university budget be cut by $\$ 3$ million unless the university agreed to stop the conference. During the Appropriations Committee's debate, the Baptist minister from Bangor addressed the group, asserting that the trustees' decision was cowardly and that the legislature must take a stand on the issue.

On March 26 the Bangor Daily News (1974j) reported that the House had "killed efforts to curtail University funds . . . and turned back efforts to blackmail the University of Maine" on a 96-38 roll call vote. On March 28 Part 2 of the budget (including the university appropriation) was adopted by both houses. Both parts of the budget were subsequently signed by the Governor.

The ministers were far more successful in damaging the university within the arena of public opinion, thereby weakening the campus' fund-raising drive. In 1973 a consulting agency hired to assess potential contributions estimated that the necessary funds would be available. In fact, the initial solicitations fell short of the target figure of $\$ 3.5$ million and the drive was extended. The drive was still going in 1983,10 years after it started. We were told by a senior university administrator of one contribution of $\$ 1$ million which was withdrawn because of the donor's opposition to the trustees' stand. More than 100 alumni returned pledge cards with statements such as "not until you get the queers off campus." Lawyers who were in contact with university officials told them that clients were changing their wills to withdraw support from the university.

On April 20, 1974, the two-day gay conference began. Those attending the conference were welcomed by the Acting Dean of UMO's College of Arts and Sciences. The conference was addressed by two national gay activists, Nathalie Rockhill, women's spokesperson for the Gay Activists Alliance of New York City, and Monty Manford, president of the Gay Activists Alliance. The remainder of the conference consisted of workshops on such issues as negative attitudes toward homosexuals and public harassment of homosexuals.

Although there were threats of violence against the conference, it took place without incident. With the exception of a few signs condemning homosexuality, there were no demonstrations or other forms of conflict.

\section{THE GAY RIGHTS PLANK AND THE DEMOCRATIC PARTY}

Nineteen seventy-four was an election year in Maine in which the governorship and state legislative seats were contested. The Maine Democratic Party, in its convention of the weekend of May 18,1974 , adopted a platform which included a plank defending the rights of homosexuals. The plank stated:

As an extension of the traditional Democratic Party's regard for Civil liberties, we advocate that the Human Rights Act be amended to forbid discrimination on the basis of homosexuality. We also urge the legislature to appropriate sufficient funding to allow the Human rights Commission to function effectively and to strengthen existing legislation (Portland Press Herald, 1974a).

The plank was proposed by the Democratic platform committee. Party activists who were also members of gay rights groups were among those who testified before the committee; they also 
made their presence felt during the convention. The plank was opposed by the conservative wing of the Democratic Party which supported the protection of the civil rights of homosexuals but feared that the party would come to be seen as "endorsing the practice of homosexuality" (Bangor Daily News, 19741). The plank was adopted by a narrow margin in the convention's closing hours at a time when many of the delegates, particularly those from the conservative wing, had left for home.

When the plank was publicized, it became the focus of controversy. Four of the five Democratic candidates for governor disassociated themselves from the plank and one candidate tried, unsuccessfully, to have the convention recalled so that the plank could be repealed (Bangor Daily News, $1974 \mathrm{n}, 1974 \mathrm{o}, 1974 \mathrm{p})$. While the plank rekindled the public controversy aroused by the gay conference, the controversy over the plank was not as intense as the controversy over the conference, nor did it last as long. One indicator of the extent of a public controversy is the number of letters to the editor. The News published 85 letters to the editor on the conference and 11 on the plank. The last letter on the plank was published on July 11, 1974. By the time of the election in November, we found that the plank was rarely mentioned in the press.

\section{THE CASE OF LEGAL REFORM}

The fundamentalist group was unsuccessful in the legislature because its demands were couched in terms of punishing the university. There was no strong pro-homosexual sentiment in the legislature. Nonetheless, in June 1975 the legislature decriminalized homosexual practices between consenting adults. This law was passed virtually without discussion either in the legislature or among the public.

The provision to decriminalize homosexual activities was part of a general revision of Maine's criminal code. The commission to revise the code had been established by the legislature in 1972 . The legislature created the commission because the criminal code was perceived as overly complex and containing a number of unenforceable laws. The legislature perceived the code itself as contributing to a larger social problem characterized by overburdened courts, increasingly ineffective law enforcement, and rising crime rates. Members of the commission were drawn from the more prestigious and generally more conservative members of the legal system, and the proposed revision was supported by the legal elite.

In revising the criminal code, the commission made use of the model penal code developed by the American Law Institute. Included in the model code was the elimination of a number of "victimless" crimes, including homosexual intercourse between consenting adults. This recommendation was adopted by the Maine commission, which was also influenced by the 1974 decision by the American Psychiatric Association to remove homosexuality from its list of mental illnesses (Bangor Daily News, 1974k),

The revised criminal code, of which the provision on homosexuality was a part, was not passed by the legislature on the basis of widespread popular support. Rather, the public and the legislature as a whole had little knowledge of the suggested revision on homosexuality. The bill was extremely complex, containing 170 pages of detailed revisions. The political reporter believed no more than 20 of the state's 184 legislators read the bill carefully.

After the code was revised, a series of public meetings was held throughout the state to explain the proposed revisions and consider citizen objections. To the best of our knowledge, the proposed revision of the law on homosexual intercourse was raised only once at these meetings. The bill did not make it clear that this law was being abolished, as the particular provision did not mention homosexuality specifically. Rather, it listed what types of gross sexual misconduct should be illegal; homosexual activities were not included on the list. Thus, a careful reading of the bill, plus detailed knowledge of the existing criminal code, would have been necessary for someone to know that homosexuality was to be decriminalized. Furthermore, the media did not publicize the proposed 
change. While some of the revisions were treated extensively in the media, particularly by the News, the proposed decriminalization of homosexual intercourse was almost never mentioned.

The proposed revisions of the criminal code aroused little public opposition and easily passed through the legislature. In 1977-two years after the revisions became law-most of our informants, except those who were intimately involved with the legal system, believed that homosexual activities were still a felony. These included the fundamentalist minister we interviewed.

\section{A SECOND GAY CONFERENCE}

On April 5, 1975, a second conference was held at Bangor Community College, an affiliate of UMO. The conference was attended by about 100 men and women from across the state. The conference was addressed by two speakers: Suzanne Breeding, an activist from Brunswick, Maine, and Allen Young, a member of the Gay Activist Alliance of New York City. Both speakers focussed on the isolation of Maine's homosexuals imposed by the state's geography and cultural atmosphere. The conference then broke up into a number of workshops. We did not find any letters in the News discussing the conference, and there was virtually no public debate.

\section{MEDIA COVERAGE}

The first gay conference received the most extensive coverage. Between January 24, 1974, the date of the article reporting the proposed conference, and April 22, 1974, the date of the article reporting the results of the conference, the News carried 39 stories on the conference. Fifteen of these appeared on the front page. During this period the News also printed six editorials on the topic, three guest editorials (editorials written by News readers), and 85 letters to the editor.

With the exception of letters to the editor, this coverage was strongly weighted in support of the university's position and the rights of homosexuals to freedom of speech and assembly. Five of the six editorials either supported the homosexuals' First Amendment rights or deplored the controversy because of the negative effect it might have upon the university. These editorials urged the legislature not to allow the controversy to influence its deliberations on the university budget and upheld the university as the appropriate site for free speech. No editorial supported the fundamentalists' position, though two editorials did support their right to free speech after the radio stations curtailed discussion by the ministers on the air. Two of the three guest editorials supported the university's position. The third supported the fundamentalists' right to free speech but also stated that the radio stations should provide equal time for rebuttal. Only two articles in the News contained long excerpts from interviews with fundamentalist ministers or long excerpts of their public statements. On the other hand, articles frequently reported the statements of university officials and other university supporters in detail.

Three other aspects of the News' coverage should be noted. First, in its first editorial on the issue the News attempted to diffuse conflict by defining the trustees' decision as a defense of freedom of speech and assembly, and as a "willingness to guard the precepts that are so vitally important to the pursuit of learning" rather than as a sanction of homosexuality on campus (Bangor Daily News, 1974c). Second, the News did not display its initial coverage of the gay conference in prominent locations in the paper. A long story on the meeting of the board of trustees was placed on the front page and continued on the fourth page. The conference decision was briefly mentioned near the end of the story. The major story on the conference was placed on the stock market page. Third, the News' editorials strongly defended the fundamentalist ministers' right to free speech when the radio programs were cancelled or curtailed.

The other newspapers, while covering the dispute less extensively, were either relatively neutral in their coverage or, like the News, covered the dispute in a way that was relatively favorable to 
the university. The controversy was mentioned in radio and television state and local news but, like most topics, received little extensive coverage. Spokespersons for the university appeared more frequently than fundamentalist supporters on radio and television talk shows. The one clear media advantage held by fundamentalist spokespersons was the radio broadcasts of the fundamentalist ministers, but this advantage was short-lived.

The formation of the Wilde-Stein Club and the first gay conference were covered extensively by the student newspaper. The Campus started its coverage earlier than the News as the gay leaders were willing to be interviewed by the Campus before they were willing to be interviewed by the mass media (Maine Campus, 1973a). The Campus ran two stories on the formation of the Bangor gay group including a long interview with its founder. When the Wilde-Stein Club was formed, the Campus ran one story which included a long interview with its chairperson. Once the conference was announced, the Campus covered it closely, publishing 22 stories, 10 editorials, and two guest editorials between January 24 and April 23, 1974. All of the Campus's editorials strongly supported the club. For example, when the student senate voted not to grant the club's request for travel funds for the conference, the Campus editorial rebuking the senate was headlined "Elected Cowardice" (Maine Campus, 1974b). One guest editorial also supported the club while the other was by one of the fundamentalist ministers.

The second gay conference, on April 5, 1975, was not covered as extensively by the News. Two short articles announced the conference, the organizers' purposes in holding it, and the topics to be covered, but each article was less than 350 words long (Bangor Daily News, 1975a, 1975b). Two days after the conference, the News ran a 500 word article summarizing speeches and quoting two speakers (1975c). No editorials or guest editorials were published, nor did the News print any letters to the editor about the conference. Coverage in the other state papers and on radio and television was also brief. The Campus ran only two articles on the conference and no editorials. We did not hear the conference mentioned on any of the ecumenical broadcasts we monitored.

The revision of Maine's criminal code was covered extensively, particularly by the News. However, the proposed decriminalization of homosexual intercourse was mentioned briefly in only four stories. For example, one story said: "The code also reduces the penalties for prostitution, and removes laws against sexual acts between consenting adults such as homosexual behavior, fornication, and adultery" (Bangor Daily News, 1975d).

In contrast, the Democratic plank on gay rights was extensively covered. Between May 8 and July 11, 1974, the News published nine stories, three editorials, and two guest editorials about the gay rights plank. In addition the News printed 11 letters to the editor. The editorials opposed the plank on the grounds that, while homosexuals should have the right to live without harassment, homosexuality should not be viewed as a legitimate sexual preference. The News held that legitimating homosexuality would weaken the social fabric and reduce social pressures upon gays to find treatment, and that the enforcement of such a bill would infringe "upon the rights of those who choose not to employ a homosexual for other than purely prejudicial reasons" (Bangor Daily News, 1974q). The News also cautioned the Maine Democratic Party against involvement with this issue. Most of the News' stories contained statements by those supporting the plank but more extensive statements by those opposed. One story, however, was devoted to the positive experiences of a gay man who decided to "come out." In contrast to the guest editorials on the first gay conference, none of which were hostile to homosexuals, one of the two guest editorials condemned gay liberationists for their "degrading, filthy ideas" (Bangor Daily News, 1975r). The second guest editorial, written by the chairperson of Gay Support and Action, defended the rights of homosexuals.

Other major newspapers also gave the dispute fairly extensive coverage. In contrast to the News, the Portland Press Herald weakly supported the plank as a civil rights measure (1974b). The dispute was also covered on radio and television but, like most issues, did not receive extensive coverage. 


\section{INTERPRETATION}

\section{The Role of the Media}

As Molotch and Lester (1975) indicate, "newsworthy" occurrences do not automatically appear in the media. Editors must decide what items are newsworthy, and their ability to make these decisions gives them considerable influence (Ross and Staines, 1972). Because of this influence, the criteria editors use to select newsworthy stories must be studied.

The four events show very different levels of media coverage and public awareness and arousal. We shall concentrate upon the News in discussing why the differences in coverage occurred. Two of the editors' criteria are crucial: their definition of a good story, and their definition of the appropriate way to handle controversial issues. The senior editor of the News expressed his view of the first gay conference as a good story as follows: "The gay conference was dramatic. You could see a confrontation shaping up. A good news story has people in it and conflict." According to a News reporter we interviewed, reporters on the News had additional criteria for a good story:

The gay conference was a story that just caught on. Further, it was an easy story to write. It continued from day to day. It was flamboyant and sensational. It was also an easy story to cover. You could go out and interview someone and then write it up.

By these criteria, the disputes over the first conference and the Democratic planks were good stories. The actions of the commission to revise the criminal code were not, because no conflict was involved. The report of the commission was long and technical, and the work of the commission consisted of long meetings, not open to the public, in which lawyers engaged in technical discussions.

In covering controversial issues, the News appeared to follow three guidelines: (1) readers should be informed; (2) each side should receive equal coverage; (3) the issue should be handled in a lowkey fashion so that divisions were not inflamed. The desire not to inflame issues reflected the paper's image of itself as a "responsible" paper. The paper also saw itself as a reactive one; that is, its editors saw their duty as reporting conflict rather than stimulating or exacerbating it. The senior editor of the News said:

It would be arrogant for us to suppress news simply because we believed it would harm or benefit some segment of society. Our concerns may influence how we play it and how we report it, but we would still report it. . . . If conflict exists, we will report it. If no conflict exists, we do not see our role as leading the way into controversy. We see this as the responsible position for a newspaper to take.

We were told by this editor that if there had been conflict over the homosexual issue in the commission's report "we would have explored it in detail." However, there was little conflict since few people knew of the commission's recommendation. The News'conception of itself as a responsible newspaper led it to give this recommendation minimal coverage. Similarly, the News gave little coverage to the second gay conference. According to the same senior editor, this was because people were not reacting to it: in other words, there was little conflict. Using the editor's criteria, it would not have been responsible behavior for the News to cover the conference extensively.

We could have created a controversy by dredging up reports from 1974, printing the notice of the conference on page one, etc. But I didn't see that that would contribute to what we're trying to do for readers, to give them a balanced and responsible newspaper.

The concept of responsibility leaves open the question of responsibility to whom? While the News frequently opposed increased budgetary allocations to the university, in other areas the university was one of the organizations to whom the News felt responsible. We were told by the senior editor that while the News felt an obligation to cover controversial issues, it attempted to cover these issues in such a way as not to damage the university.

Our research suggests that the News did not feel the same level of responsibility to the fundamentalist ministers. Asked to list the types of groups and organizations to whom the News 
was highly responsive, the editors did not mention the fundamentalist ministers. The experience of the ministers also sliggests that the News was not highly responsive to them. The minister we interviewed had contacted the News in an effort to get more extensive coverage of their position. He said that during his meeting with the News editor he "felt backed into a corner" and "attacked for trying to rob people of their human rights."

This meeting was not the only point at which the ministers were attacked by the News. In its first editorial, the News stated: "Ironically, the initial moans of disenchantment came from clergymen, those who are supposed to embody tolerance, compassion, understanding, and societal sophistication" (1974c). Occasionally, the ministers were also ridiculed. The story on Reverend Bubar's initial attack on the Wilde-Stein Club began:

Maine's apostle of the "drys" - the Rev. Benjamin Bubar of China - has taken on a new "foe," a clique of homosexuals at the University of Maine's Orono campus who are assembled under the banner of the "Wilde-Stein Club.". . . The Rev. Mr. Bubar, who traditionally fights booze and gambling, might have stayed on the track had it not been for one enterprising member of the Wilde-Stein Club who put the club public by posting a notice in The Associated Press about a December dance (Bangor Daily News, 1974a).

We asked the senior editor why, throughout the controversy, more space was not devoted to the fundamentalist ministers. He responded:

We did not view their statements as news since everyone expected them to say what they did. This may have been a bias on our part. We could have sought out interviews with them, and perhaps we were remiss in not doing so. But we didn't . . . I think we are responsible enough to know when coverage just exacerbates a situation and doesn't help it.

The News' coverage was also influenced by its commitment to First Amendment rights and its conservative political views. Its editorials consistently stated that the university should be supported because its actions supported the rights of free speech and assembly. When the News suspected that university pressures on the radio stations undermined the ministers' rights of free speech, its editorials supported the ministers' rights and invited those with definite knowledge of why the radio programs were cancelled to write guest editorials in the News. (No such editorials appeared.) The News did not support the Democratic Party's gay plank because, we believe, the plank did not address freedom of speech and assembly. Rather, the plank was aimed at eliminating social discrimination, notably in employment and housing. Further, the gay plank, along with certain other planks, was a handy flail with which to beat the Democrats, as the News headline "Demos Out-Liberal McGovern" testifies (1974m).

In summary, the News believed that controversy was news and that the dispute over the conference was a good story. As a result, it covered the dispute extensively. Its extensive coverage damaged the university. However, this damage was minimized by the paper's "responsible and reactive" stance. Space was devoted to presenting the arguments of the fundamentalists. More extensive coverage was consistent with the editors' definition of themselves as running a responsible paper.

These results raise a crucial problem in interpretation. By covering a dispute extensively, the media legitimates the demands of the conflicting parties as proper foci of public concern (Cohn and Gallagher, 1977). From this perspective the coverage given to the dispute provided some legitimacy to the fundamentalists' demands. The coverage also publicized their demands and allowed them to extend their support. But why was extensive coverage given if the News had relatively close ties with the university? It can be argued that the trustees' decision could have been given the same minimal coverage as the second gay conference or the homosexuality provision in the revised criminal code, thereby minimizing damage to the university.

Our research suggests that the extensive coverage was the result of the editors' "loss of control" (our term) over the communication process. The evidence suggests that the News attempted to de-emphasize the dispute and only started to report it extensively when it could not avoid doing so, given its criteria of newsworthy stories as stories involving conflict and the public's knowledge 
of the conflict. The News' placement of the original full story of the trustees' decision on the stock market page with only a short summary at the end of the page-one story suggests that its editors felt obligated to cover the story but did not want it to receive extensive attention. The News' first editorial may be seen as an attempt to deflect the dispute by defining the issue as one of freedom of speech and assembly rather than tolerance for homosexuality. The News published only one letter opposing the conference during a period of one and one-half weeks after the appearance of the first articles about it. This gap suggests that few people read the articles and that public opinion was not significantly mobilized until the publicity given to the university's decision by the fundamentalist ministers in their radio broadcasts and sermons. Our results also indicate that, once the dispute became extensive, the media covered it in a way that was either neutral or favorable to the university's position.

In sum, our research suggests that editors initially attempted to minimize public debate and subsequently attempted to minimize damage to the university. The editors were unsuccessful in doing so because they did not fully control the media. In particular, they did not have control over the fundamentalist ministers' radio broadcasts. The ministers were able to use these broadcasts to publicize their beliefs and gain popular support. Extensive conflict developed which editors felt obliged to cover, thereby exacerbating the damage done to the university. However, the radio stations' decisions to prevent the ministers from continuing to discuss the issue on their programs and the News' decision to cease printing letters to the editor on the issue suggest that editors were partially able to regain control over media content. This control was used to dampen the conflict in a way that reduced damage to the university. Thus, the extensive coverage given to the first gay conference does not seem inconsistent with our contention that the News had relatively close ties with the university.

\section{Relationships Between Media Coverage and Public Arousal}

Our research indicates that there is a reciprocal influence between media coverage and public arousal. Extensive public arousal over the first gay conference forced extensive coverage despite the hesitance of editors. On the other hand, the lack of public protest over the bill to decriminalize homosexual intercourse indicates the importance of media coverage to public arousal.

The contrast between extensive arousal over the first gay conference and less extensive arousal over the gay rights plank indicates, however, that coverage is not a sufficient condition for extensive arousal. The contrast is particularly striking as debates over the gay rights plank were covered relatively intensely by the News, despite its not having aroused a high level of public controversy. One measure of the extent of controversy is the number of letters to the editor. The News printed 85 letters about the first gay conference and, had it not issued a statement saying it would print no additional letters, it clearly would have received many more. The News printed only 11 letters on the gay rights plank and there was no indication that the News would not have printed additional letters had it received them. The News published 38 stories on the conference, a ratio of 2.2 letters to every story. In contrast, the News ran nine stories on the gay rights plank, a ratio of almost one story to every letter.

The News' coverage of the gay rights plank was sufficiently intense so that, if coverage were the only factor stimulating public arousal, we would have expected a high level of arousal promoting additional conflict, in turn promoting additional coverage and yet further conflict on the pattern of the first gay conference. The differences between the first conference and the Democratic plank lie not in the extent of coverage but in the active role of the fundamentalist ministers in promoting public arousal in the first instance and not the second. The ministers had two major communications channels available to them: their direct access to their congregations and their radio programs. When they were prevented from using the latter channel, they became dependent for publicity on media editors granting coverage. The ministers' experiences during the dispute over the first gay 
conference, in which after the first few stories they had great difficulty in getting their views publicized, indicated that editors would not be receptive. Realizing that they would have major difficulties in reaching a mass audience, and remembering their failure to prevent the first gay conference, the ministers decided not to try to mount major campaigns against the Democratic plank and the second gay conference. As a result, conflict over the plank was limited and we found no conflict over the second conference.

\section{The Issue Areas Within Which Claims Are Located}

Perceptions of social conditions are not totally - or even necessarily - determined by the conditions' objective characteristics. Rather, perceptions are determined by a number of factors, among the most important being the symoblic contexts within which conditions are located. Individual conditions can often be perceived as falling within different issue areas (Cohn and Gallagher, 1977; Hewitt and Hall, 1973; Ross and Staines, 1972). A key way in which power and influence are used in disputes is to affect perceptions of the issue areas in which conditions are located. Disputants seek to locate conditions in issue areas where prevailing attitudes legitimate their demands. Therefore, the choices that editors make are important in ways other than those discussed above, as their choices may influence public perceptions of the relevant issue areas.

In Maine there was a consensus within the relevant political and legal sectors on the problems of court overload and legal reform. Because the provision to decriminalize homosexual activities was classified as an issue of court reform, and because of the commissioners' prestige, those who were aware of the provision were willing to accept it. The political reporter and the legislators we interviewed said that, had the issue been defined as one involving civil rights, the provision would not have been accepted by many.

The behavior of the News was also affected by issue area perceptions. The News is a conservative paper and a strong advocate of lower taxes. It rarely supports university requests for increased budgetary allocations from the state and has been an advocate of general cuts in state spending. Nonetheless, the News gave considerable support to the university despite the fundamentalists' demand that the university budget be cut. This was largely because the News classified the demand as an attempt to punish the university rather than as part of a general program to reduce expenditures.

Because perceptions of the issue areas within which demands are located affect beliefs about the validity of the demands, we suggest that disputes will partially consist of conflict over which issue areas are relevant. The conflict over the decision of the board of trustees was initially of this nature. Conflict did not initially center on whether the proper interpretation of provisions on civil liberties extended to the expression of sexual preferences, nor did it center on whether homosexual practices were consistent with traditional, religiously based morality. Rather, one side asserted that the decision of the board violated traditional codes and would encourage further disobedience, while the other side asserted that, if the board had decided otherwise, it would have violated civil liberties. Neither side discussed the dispute within the issue areas chosen by its opponents. Rather, each asserted that its issue area was the proper one in which the dispute should be located.

To generalize, we believe this is a common situation in disputes. Each side risks losing ground by addressing the conditions within the issue areas chosen by the other, especially when prevailing attitudes within those areas legitimate the demands of the other side. Under these conditions, a debate is not likely to take place; rather the statements of each side are likely simply to reiterate the validity of its demands within the issue areas it has selected.

\section{Conflict Arenas, Power Resources, and Tactical Skills}

A range of research in social movements and interest group processes indicates that the ability of movements and groups to achieve their objectives depends upon the groups' power resources, the importance of these resources in the arena of conflict, and the skill with which these resources 
are used. Evidence indicating the relevance of these factors to our study comes from an analysis of the factors affecting the resolution of the fundamentalist demands in two arenas: the legislature and public opinion.

The fundamentalist ministers instituted an extensive campaign to bring popular pressures upon the state legislature. Despite these pressures, the ministers occupied a relatively weak position. Most legislators believed that the ministers' supporters did not constitute a politically significant segment of their constituents. While they believed most voters would disapprove of the gay conference, they also believed that votes in the upcoming election would be linked to the legislators' position on bread-and-butter issues rather than on a moral issue of this sort. The political reporter said:

There was little support in the legislature for cutting the budget, basically 20 or 30 legislators from rural areas. Only two of the major legislators favored cutting the budget. Only one of the gubernatorial candidates made any statement [against the university]. The absence of popular support for the issue was shown when he got only a few thousand votes in the Republican primary. There was little popular concern with the issue. It did not reach back into the constituencies in the way that issues such as income tax did.

In addition, legislators knew of the court decision on the gay club at the University of New Hampshire and were aware that the University of Maine might have been legally obliged to act as it did. In contrast, the university had considerable support within the legislature because of its importance to the state as the principal insitution of higher education and the primary source of research and extension work for the state's industry and agriculture. In addition, the university enjoyed substantial support in the legislature from legislators who were alumni.

The fundamentalist ministers did, however, have the power to hurt the university in the arena of public opinion and markedly damage its fund-raising ability. In this arena, the university was in a very vulnerable position because publicizing its position was likely to gain it more opposition than support from potential donors, given the rural and socially conservative nature of the state. The university therefore followed a defensive strategy, trying to avoid publicizing itself. A senior administrator said:

We tried to act, on and off campus, as if it were business as usual. We wanted to convey the impression that there was no crisis and that the issue was not worth discussion. . . We tried to fight the issue by keeping a low profile. In this case less was more. Taking an active position would have been counter-productive.

The university, however, was not able to prevent the ministers from publicizing the dispute, and it suffered from the financial losses the dispute caused.

\section{CONCLUSIONS}

The events we have described seem to illustrate the utility of the subjectivist perspective on the emergence of social problems (Mauss, 1975; Spector and Kitsuse, 1977; Tallman, 1976), as opposed to more traditional perspectives such as Merton's (1971). The university's willingness to permit a gay conference and the presence of gay people at the university were not defined as social problems spontaneously, nor on the basis of widespread support for the belief that they constituted social problems. Similarly, the decriminalization of homosexual activities did not occur because of a widespread consensus that such activities did not constitute a social problem. Rather, certain people learned of the university's activities, decided to take issue with them, and mobilized a constituency. Divisions of opinion within the state, largely along religious lines, allowed them to do so. In part because these spokespersons did not learn of the proposed legal revisions, no constituency was mobilized and no protest emerged on this issue. Further, their failure to learn was the result not of chance factors, but because of the deliberate actions of other actors.

These events also illustrate some aspects of the social dynamics through which claims about social problems gain publicity and acceptance: 
(1) Claims may be located in several different issue areas, and perceptions of the issue areas in which the claims are located affect beliefs about the validity of the claims.

(2) Conflict over claims in part consists of conflicts over the issue area in which the claims should be located.

(3) The media play an important role in the resolution of claims by influencing public awareness of claims, public perception of the issue areas in which claims are located, and public awareness of the positions of prestigious actors. Hence, access to the media is an important power resource, and a source of conflict.

(4) The choices of editors and reporters on how claims are to be reported are affected by their criteria for newsworthy stories, and their definitions of proper media behavior.

(5) When actors have access to some segments of the media, they can use these segments to create the conditions for newsworthy stories, thereby increasing their access to other segments of the media.

(6) The ability of a claims-making group to have its claims accepted depends upon the group's power resources, the importance of these resources in the arena of conflict, and the skill with which these resources are used.

Other research also suggests that widespread publicity is not a sufficient condition for mass arousal. The question therefore remains: Under what conditions must publicity be supplemented by organized efforts at mobilization?

\section{REFERENCES}

American Law Institute

1982 Model Penal Code and Commentary (Official Draft and Revised Commentary Drafted 1962). Philadelphia, PA: American Law Institute.

Bangor Daily News

$1974 a$ "Homosexual activity ires Bubar." January 2:12.

1974 b "Trustees okay gay conference." January 24:13.

1974c "The price of tolerance." Editorial. January 30:14.

1974d "Station squashes radio sermon on homosexuals." February 23:17.

1974e "University backs cost-study items." February 28:1.

$1974 \mathrm{f}$ "Tolerance at UMO is pretty intolerant." March 3:14.

$1974 \mathrm{~g}$ "Budget passes after wild session." March 8:4.

1974 h "Gay flap may bar UM funds." March 20:1.

1974i "Gay' issue hardly a jolly one for either side." March 23:5.

$1974 \mathrm{j}$ "Budgetary protest of gay conference fails." March 26:17.

$1974 \mathrm{k}$ "Psychiatric association takes vote. Homosexualism off mental-disorder list." April 19:1.

19741 "Democrats hone planks in platform." May 8:24.

1974m "Demos out-liberal McGovern." May 20:1.

1974n “Two Democratic planks spur reaction." May 21:1.

19740 "Brennan rejects party amnesty, homosexual planks." May 22:25.

1974p "Effort to rescind planks rejected - Party leader says La Fountain was absent." May 23:4.

1974q "Gay lib: The value of opprobrium." Editorial. May 28:14.

1974r "We must exercise our responsibility or we will lose it and our freedom." Guest editorial. July 3:14.

1975a “"Gay' symposium slated." March 21:10.

1975b "Gays gather at Bangor campus." April 5:19.

1975c "Gays discuss problems of isolation in Maine." April 7:11.

1975d "Senate prepared criminal code." June 7:17.

Cohn, Steven F.; and James E. Gallagher

1977 "Crime and the creation of criminal law: A partial model." British Journal of Law and Society $4(2): 220-236$.

Hewitt, John P., and Peter M. Hall

1973 "Social problems, problematic situations, and quasi-theories." American Sociological Review 38(3):367-374.

Maine Campus (Orono)

1973a "New Bangor gay group helps members find themselves." April 12:4.

1973b "Gay leader vows 'Students will be educated'." November 15:8.

1974a "Trustee decision ends hedging by administration." Editorial. January 25:2.

1974b "Elected cowardice: Blaming the constituents." Editorial. February 8:5. 
Mauss, Arnold

1975 Social Problems as Social Movements. New York: Lippincott.

Merton, Robert K.

1971 "Epilogue: Social problems and sociological theory." Pp. 793-846 in Robert K. Merton, and Robert Nisbet (eds.), Contemporary Social Problems. New York: Harcourt Brace Jovanovich.

Molotch, Harvey, and Marilyn Lester

1975 "Accidental news: The great oil spill as local occurrence and national event." American Journal of Sociology 81(2):238-249.

Portland Press Herald

1974a "Convention backs gays, amnesty." May 19:1.

Ross, Robert, and Graham L. Staines

1972 "The politics of analyzing social problems." Social Problems 20(1):18-40.

Spector, Malcolm, and John I. Kitsuse

1977 Constructing Social Problems. Menlo Park, CA: Cummings.

Tallman, Irving

1976 Passion, Action and Politics: A Perspective on Social Problems and Social Problem Solving. San Francisco, CA: W. H. Freeman.

\section{Cases cited}

Gay Students' Organization of University of New Hampshire v. Bonner, 509 S. 2D 652, 1974 (1st Circuit). 